\title{
Historical geomorphic analysis of Someșul Mic River (NW Romania) channel spatial and temporal behavior, as a background for the assessment of present day morphological state of the river
}

\author{
Ioana PERȘOIU ${ }^{1,2^{*}}$, Maria HOSU ${ }^{3}$ \\ 1"Emil Racoviță" Institute of Speleology, Romanian Academy, 5-7 Clinicilor Street, 400006, Cluj-Napoca, \\ Romania \\ 2"Ștefan cel Mare" University, Stable Isotope Laboratory, Universității 13, 720229, Suceava, Romania \\ 3"Babeș-Bolyai" University, Faculty of Geography, 5-7 Clinicilor Street, 400006, Cluj-Napoca, Romania
}

Received 21 November 2019; Revised 30 November; Accepted 3 December 2019

*Correspondence to: Ioana PERȘOIU e-mail: ioanapersoiu@gmail.com

\begin{abstract}
In the context of the increased interest on integrating the complex spatial and temporal response of fluvial systems to human impacts into the process of assessing the ecological state of the rivers and in promoting a sustainable river management European countries have developed a multi-scalar, hierarchical, process based hydro-morphological framework focused on understanding the river functioning and evolution as a basis for interpreting current conditions. In this context, the goal of this paper is to demonstrate the usefulness of systematic historic and present day geomorphic analysis along channel reaches with distinct typologies in order to generate a better image of river morphology as a background for assessing its present morphological state. The historical geomorphic analysis of Someșul Mic River's channel dynamics during the past 250 years has shown that the main controlling factor is climate through its centennial - decadal scale variations in magnitudes and amplitudes of flood events, while the local geological conditions and hydrotechnical works having subordinate effects. The reference condition in assessing the present day morphological state of the river was defined based on channel typology and dynamics between AD 1860 - AD 1970, reflecting a river state far from a pristine condition, but characterized trough human impacts maintained bellow the river sensitivity to disturbances. The Morphological Quality Index (MQI) was calculated for 17 distinct channel reaches. Its values indicate the high geomorphic degradation of the river induced by hydrotechnical interventions along the channel. Very poor conditions are concentrated mainly along the upper reaches of the river, while further downstream the river is in a dominantly moderate deterioration state. The resulted image has the potential to better identify the critical reaches along this river, and the main disturbatory elements acting on them, in order to support better projections on possible channel trajectories and subsequently river management actions.
\end{abstract}


KEYWORDS

channel planform dynamics; evolutionary trajectory; boundary conditions; sensitivity; resilience; present day morphological state

\section{Introduction}

River channelization and diversion, gravel extractions, groyne and dam constructions are known to have significant impacts on fluvial forms and processes. Some of these interventions have rapid and perceptible effects on river hydro-morphology and its social and ecological functions, while others impact rivers decades after construction as a consequence of long term channel adjustments (Knighton, 1998; Brierley and Fryirs, 2005; Kondolf and Piégay, 2016).

In the context of the increased interest on integrating the complex spatial and temporal response of fluvial systems to human impacts into the process of assessing the ecological state of the rivers and in promoting a sustainable river management (e.g. Brierley and Fryirs, 2005; Brierley et al., 2008; Brierley et al., 2013; Rinaldi et al., 2013 a, b; Rinaldi et al., 2016; Kondolf and Piégay, 2016; Gurnell et al., 2016 a, b) European countries have developed and/or extended a series of hydro-morphological tools in order to assess, manage and monitor the ecological status of rivers (Rinaldi et al., 2017). This process has been accelerated by the implementation of the EU Water Framework Directive (WFD; Directive 2000/60/EC) which introduced hydro-morphology as an important component in the process of assessment and management of river ecosystems. In the initial approach, hydro-morphological assessment was considered equivalent to physical habitat survey, used to offer a rapid overview on river status. A series of limitations have become evident (Belletti et al., 2015; Rinaldi et al., 2017), the most evident ones being related to: a) limited space of investigation (fixed length of the investigated river reaches, few hundred meters long) which cannot offer a good perspective on the context of river condition and do not permit an accurate diagnosis on causes of alterations; b) the ambiguous notion of "reference conditions", defined based on the statistical analysis of empirical data, not always being relevant at local scale; and c) the terminology used to describe geomorphic units that seemed to lack a good correspondence with present state-of-the-art classifications in fluvial geomorphology. Therefore, in opposition with the physical survey procedure, an increased tendency to develop frameworks of hydro-morphological approaches and methods which focus on understanding the river functioning and evolution as a basis for interpreting current conditions emerged (e.g. Winterbottom, 2000; Liébault and Piégay, 2001, 2002; Brierley and Fryirs, 2005; Dufour and Piégay, 2009; Surian and Rinaldi, 2003; Rinaldi et al., 2003, Rinaldi et al., 2013 a,b). These perspectives introduced process-based methods which explicitly take into consideration both spatial and temporal changes of the investigated river channels.

In Romania, the present-day monitoring system ("Sistemul de Monitorizare Integrată a Apelor din România" - S.M.I.A.R.) for assessing and classifying river sectors ("corpuri de apa") is connected to the national network of gauging stations, totalizing a number of ca. 1750 evaluation points. S.M.I.A.R. is projected to cover the entire diversity of river typologies defined for the Romanian territory in accordance with the broad river typologies established at European level, and includes habitat evaluation, completed by physico-chemical measurements and hydro-morphological characterization of the selected river sectors. The evaluation process covers $500 \mathrm{~m}$ standard river reaches, centered on the gauging stations. The outcomes of the present monitoring system are translated in qualificatives on the quality of river ecosystems and the degree of river change when compared with a reference condition, defined as "natural conditions". The rivers are evaluated with a periodicity of 6 years, the last evaluation being included in the National Plan of Water Management 2016 - 2021 (http://Www.rowater.ro).

The existing studies on spatial and temporal channel changes in Romanian rivers (e.g. Amăriucăi, 2000; Rădoane and Rădoane, 2005; Dumitriu, 2007; Rădoane et al., 2010; Perşoiu, 2010; Perșoiu and Rădoane, 2011; Ioana Toroimac et al., 2010; Armaș 
et al., 2012; Rădoane et al., 2013 a, Rădoane et al., 2017) are still limited in temporal and spatial coverage. Further, they are not unitary in terms of resolution and offer different perspectives on channel responses to various controlling factors (e.g., the adjustment of river channels downstream from dams, the effects of meander cutting and river channel corrections, the effects of decreasing sediment loads etc.). Even with this inconvenient, these studies show that human interventions on the geomorphological fluvial systems are responsible for significant changes in sediment delivery rates, variability of riverbed deposits, as well as in the hydrologic regimes of the present-day channel dynamics, with large consequences on river ecosystems. However, none of these indicators are included in the process physical survey procedures used in the evaluation and classification of Romanian rivers.

The goal of this paper is to demonstrate the usefulness of systematic historic and present-day geomorphic analysis along channel reaches with distinct typologies in order to obtain a better image of river morphology as a background for assessing the ecological state of the rivers and project sustainable management actions. The case study ex- emplified here is Someșul Mic River, located in NW Romania that has been heavily impacted by human activities in the past several decades. Our objectives are 1) analysis of the general spatial and temporal patterns of the river's channel over the past ca. 250 years; 2) disentangling the natural and human controls over the river's dynamics; 3 ) establishment of the moment and meaning of reference condition and 4) evaluation of the present-day morphological status of the river.

\section{Study area}

Someșul Mic River is a medium size river $(100 \mathrm{~km}$ long, QI = $22 \mathrm{~m}^{3} / \mathrm{s}, \mathrm{A}=3774 \mathrm{~km}^{2}$ ), formed at Gilău (presently in the Gilău Reservoir) at the junction of Someşul Cald and Someşul Rece Rivers, two tributaries draining the northern flank of Apuseni Mountains. Its upper basin overlaps the high-altitude Apuseni Mountain (Muntele Mare - Gilău Mountains and Bihor Mountains) and the median and lower basins are located within the Transylvanian Depression (Someşan Plateau, Feleac Hills and Transylvanian Plain, Fig. 1).

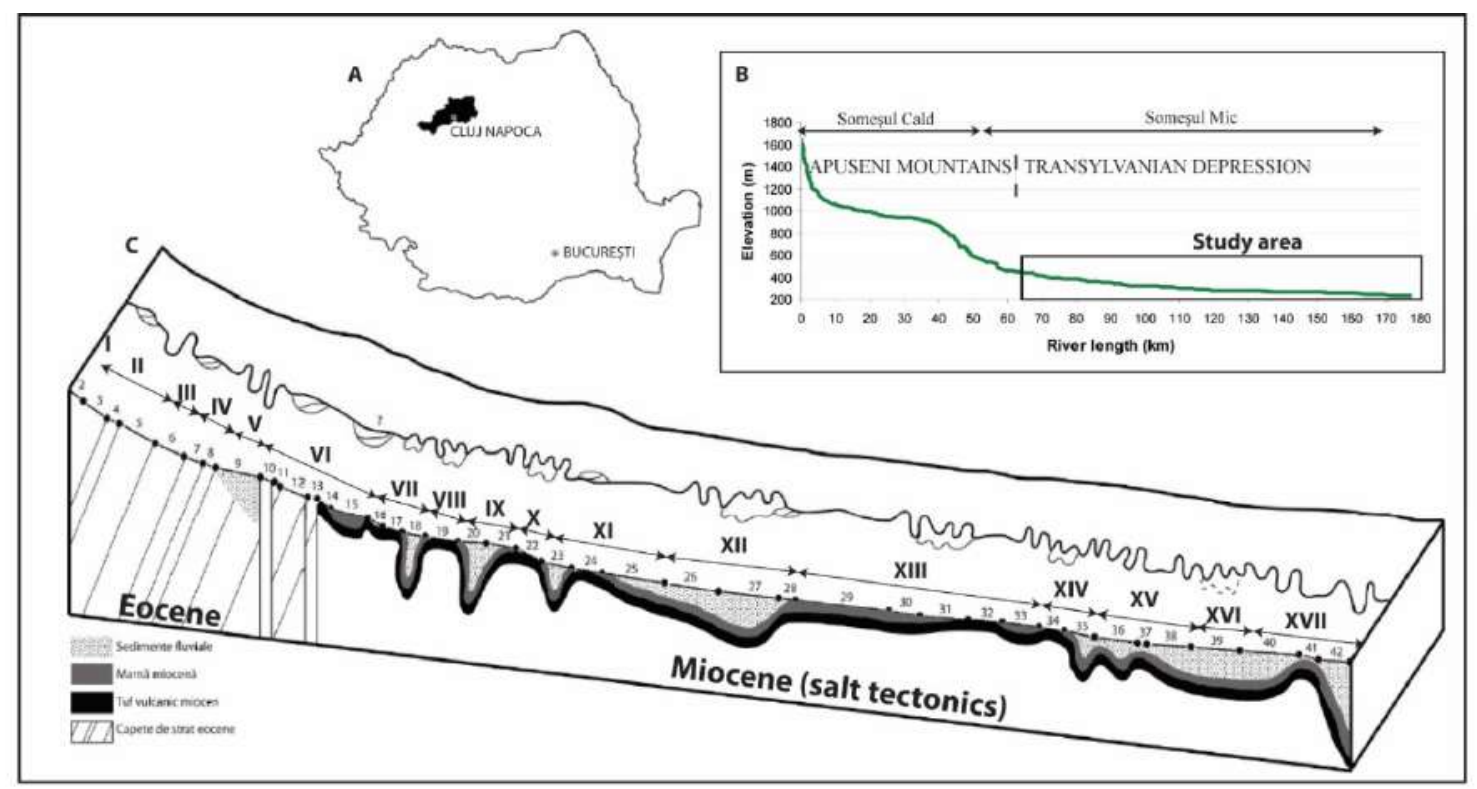

Figure $1 \mathrm{~A}$ - Location of Somesul Mic drainage basin; B - Someşul Mic River: location of the study area along its longitudinal profile; C - Model of longitudinal profile channel patterns alternation as adjustments to local geological conditions, reference year AD 1860 (II ${ }^{\text {nd }}$ Austro-Hungarian military survey). The 42 natural channel reaches were grouped in 17 main ones, based on their present-day status related to human impact, i.e. reaches completely disturbed from its previous patterns alternating with those with more local interventions, which partly preserve their natural forms 
The climate of the area is temperate continental, with mean annual temperatures of $8.4^{\circ} \mathrm{C}$ and mean annual rainfall of $582 \mathrm{~mm}$. The main source of discharge (>50\%) is in the mountainous area (23\% of the drainage basin). By contrast, the suspended load is mainly delivered from the hilly area in the middle and lower parts of the drainage basin, where the presence of friable rocks and the less protective vegetation cover favors an increased land susceptibility to erosion (Pandi, 1997).

The lithology of the drainage basin is dominated by sedimentary rocks ( $80 \%$ ), whereby $94 \%$ are Eocene and Miocene deposits in the hill domain (limestone, marls, clays, volcanic tuffs). Metamorphic (crystalline schists) and magmatic (the Gilău Granite, Paleocene andesite) rocks preferentially located in the mountainous area, make-up the remaining 20 $\%$. Two large scale knick points, hundreds of meters high, are present along the longitudinal profiles of the two tributaries, imposed by different resistance to fluvial erosion of the crystalline schists and Gilău Granite (Posea et al., 1974, Ficheux, 1996, Fig. 1). The drainage basin is completely included in the area of minimum seismic activity in Romania, with an uplift rate of $0-1 \mathrm{~mm} /$ year in the Apuseni Mountains (lower in the Transylvanian Depression, Zugrăvescu et al., 1998). The vegetation is represented by deciduous forests at low and mid altitudes (230 - 800 m), mixed forests of Fagus and Picea at $800-1300$ $\mathrm{m}$ altitudes, followed by coniferous species at 1300 - $1800 \mathrm{~m}$ and subalpine associations over $1800 \mathrm{~m}$. At lower elevation, the natural vegetation was largely replaced by agricultural fields.

Someșul Mic River has a $4 \mathrm{~km}$ wide and $170 \mathrm{~m}$ deep valley, with 8-9 fragmentary distributed fluvial terraces (Posea, 1962; Savu, 1964). The floodplain is well developed with a maximum width of ca. $2 \mathrm{~km}$. Its main particularities are the frequent change of the width associated with a complex alternation of channel types (sinuous - meandering - anabranching reaches; alluvial and mixed channels) and humid - dry areas (Perșoiu and Rădoane, 2011). This complex morphology is imposed by slight vertical displacements $(0.1-1 \mathrm{~mm} /$ year, Zugrăvescu et al., 1998) with local uplifts and subsidence in the Palaeogene domain (Gilău - Cluj-Napoca) and diapiric alignments in the Miocene domain (Cluj-Napoca Dej) (Ciupagea et al., 1970; Krezsek and Bally, 2016).

\section{Human impact}

Palaeoenvironmental reconstructions and synthesis in NE Hungary and NW Romania (e.g. Sümegy, 1999; Feurdean and Astaloș, 2005; Feurdean et al., 2013a, b; Feurdean and Tanțău, 2017) attribute the first signs of agriculture in the Somes drainage area to early Neolithic communities, approximately 7500 years ago. More continuous and abundant signals of human impacts on vegetation are associated with pastoral activities and agriculture during the late Bronze/early Iron Age (3500 years ago), Roman Age (2000 years ago), and the onset of Middle Age (the last 1000 years), with a maximum reduction of natural deciduous forest assemblages during the last ca. 500 years. These human induced changes on drainage basin vegetation composition and structure had probably notable consequences on sediment load discharges as reported elsewhere in Europe (e.g. Hoffmann et al., 2008). Recent data on palaeofluvial archives from NW Romania attest an increased vertical aggradation rates of the floodplains starting with the Bronze Age along the small rivers draining Transylvanian Plain (Feurdean et al., 2013b; Perșoiu et al., 2016) and during the last 450 years as reported along the lower Someș Plain (probably related to intensive Fagus forest exploitation at mid elevations, Robu, 2018).

At local scales, the archeological and historical findings along the river and in its floodplain perimeter show continuous presence of humans since the Bronze Age (and likely before), with permanent settlements, roads, bridges. The medieval documentations of mills attest direct human induced deviations of flows along selected reaches, while local to regional scale channel straightening and drainage of humid areas are reported starting with the $18^{\text {th }}$ century.

For more recent times, i.e. the last ca. $150-50$ years, Romanian rivers were subjected to significant changes similar to those reported throughout Europe (Rădoane et al., 2017). The main human interventions with traceable effects on river flow regimes and morphologies are: 
Regional land use changes triggered by policy/governance

Massive forest exploitation in the mountainous catchment areas emerged since the late XIX ${ }^{\text {th }}$ century (related to the first waves of industrial revolution); this phenomenon accelerated during the first decades of the XX'th century (Munteanu et al., 2014). After the implementation of the 1921's agricultural reform (that endowed the local communities with forests and pastures, Ciomac and Popa - Necşa, 1936), large areas of former forested fields were replaced by extensive agricultural and pastoral areas (Giurgiu, 2010). The next important land use changes occurred since 1950 - 1955, being related to the large scale collectivization programs and erosion control works, including reforestation (Chiriţă, 1981). After 1989, the abandonment of a series of agricultural and pastoral fields was complemented by deterioration/destruction of many of the previous erosion control works and a new increase in forest cover loss in the mountainous areas (Griffiths et al., 2014; Munteanu et al., 2014).

\section{Dams construction}

Between 1960 and 1989, approximately 260 large dams were built along the main Romanian rivers. They control over 13 billion cubic meters of water, ca. $1 / 3$ of the total discharge along the fluvial network, and have retained more than 200 million $\mathrm{m}^{3}$ of sediments. In the study area, the most extensive hydrotechnical interventions were performed between 1959 and 1983 (Pop, 1996). Sixteen dams were constructed along Someșul Cald, Someșul Rece (i.e., Beliş - Fântânele, Tarniţa and Gilău Lakes) and Someşul Mic River (Florești Reservoir). They have the capacity to retain $84 \%$ of the flow discharge, and impose its artificial redistribution throughout the year. A second important modification is the almost complete elimination of floods, especially after 1983, when Beliş - Fântânele Reservoir became functional. Sediment trapping behind the dams induced channel incision along the Someșul Mic River, Armencea et al. (1980) showing a $2.5 \mathrm{~m}$ incision downstream of Gilău Reservoir within four years after the construction, while Şerban (2007) have shown a generalized channel incision along the first $30 \mathrm{~km}$ after Gilău, attenuated downstream and then replaced by aggradation.

An explosive development of micro-hydropower stations along the mountainous rivers draining the Carpathians was recorded during the past 10 years, with a peak between 2008 and 2013, with a still not well understood impact on local flow regimes and further downstream hydro-morphological consequences.

\section{Riverbank protection structures and levees}

Local interventions in the humid areas along the floodplain were already reported during the late $\mathrm{XVIII}^{\text {th }}$ century, mainly along the lower reaches of Someșul Mic. They became more extensive in the $\mathrm{XIX}^{\text {th }}$ century, when desiccations and artificial meander cutoffs were performed in urban areas. The river bank protection structures and levees were extended in the $X X^{\text {th }}$ century (ca. $1950-1990$, especially after the large scale 1970-1975 flood events). Direct interventions along the Someşul Mic River (bank stabilization, artificial meander cutoffs and dykes) were made within or adjacent to settlements, in areas susceptible to high rates of lateral erosion, avulsion or frequent floods. Between Gilău and Floreşti Reservoirs the flow is diverted through an artificial channel, while the natural channel is partly abandoned. In the perimeters of Cluj-Napoca and Gherla towns, the river is completely channelized. Dykes and bank stabilization works dominate the river morphology between Cluj-Napoca and Apahida, while further downstream they are more local and fragmentary, which give the river a more natural aspect, characterized by alternation of sinuous and meandering reaches, and one anabranched reach (between Răscruci and Bonţida).

\section{Gravel extractions}

This activity peaked during the communist era (1970-1989) along the entire Romanian territory, and diminished considerably after 1989, with a new increase related to economic developments of the 2000s (Rădoane et al., 2017). Along Someșul Mic River, more than 30 gravel extraction points were active during the last 40 years, located both in the channel perimeter and in its near vicinity, and concentrated preferentially along the channel reach 
between Gilău and Florești Lakes and downstream from Sânnicoara (Fig. 1).

No data is available on the volume of extracted gravels or on the impact of this activity on channel morphologies and their temporal behavior. However, similar patterns with the ones reported elsewhere along the Romanian rivers (e.g. Moldova, Siret; Rădoane and Rădoane, 2009) are expected. These studies reported at least a doubling of volumes extracted during the past 20 years compared with 1969-1981 period, resulting in channel incision $(1.5-4 \mathrm{~m})$ and increase of suspended load.

In synthesis, the above mentioned aspects offer a still incipient image on millennial and historical human impacts on fluvial network and flow regimes. But even so, they do attest that "the river, before the large scale human interventions from the last six decades, was not in pristine conditions, as the human imprints on flow regimes and channel morphologies have roots traceable to at least the past 3000 years".

\section{History and evolutionary trajectory of the river morphology}

\subsection{Materials and methods}

The investigations on the spatial and temporal behavior of Someșul Mic River is based on seven sets of cartographic maps and one set of orthophotos, with the years $A D$ 1764, $A D$ 1860, $A D$ 1890, $A D$ 1945, AD 1956, AD 1970, AD 1977 and AD 2005 as reference moments (Table 1 ). The materials covering the last ca. 150 years were used to provide successive morphometric measurements along the longitudinal profile of the following parameters: floodplain width and number of channels; and, along the unique/main channels, measurements of length, sinuosity, radius of curvature $(R c)$ in the meander bents, bank elevation and bankfull channel width and slopes. With the exception of Rc, determined from the circumscribed circles of the considered meander bents, the measurements were performed at the intersection points along the $250 \mathrm{~m}$ spaced cross sections on the central axis of the floodplains with the central axis of the main/unique channels. Further, we defined channel reaches with distinct planform typologies, using AD 1860 as reference moment. Additional information on present-day channel and floodplain characteristics (field surveys), historical channel planform behavior (visualization of planform river changes during the past 250 years) and available data on local geological conditions (geological maps, hydrogeological investigations) were used to establish the limits between successive channel reaches (Figs. 1, 5).

Flow regimes before AD 1974 (Anițan, 1974), together with measurements on unique/main channel bankfull slopes and bankfull widths for the $A D$ 1970 reference moment, and GIS based estimated on drainage basin surfaces associated to each considered channel reach were used to generate specific stream power $\left(\mathrm{W} / \mathrm{m}^{2}\right)$ at bankfull flow, (Table 2, Fig. 6), using the following formula:

$\mathrm{sSP}=\rho g \mathrm{Q}_{1.5} \mathrm{~S} / \mathrm{w}$

where,

$\rho=$ density of water $\left(1000 \mathrm{~kg} / \mathrm{m}^{3}\right)$,

$g=$ acceleration due to gravity $\left(9.81 \mathrm{~m} / \mathrm{s}^{2}\right)$,

$Q_{1.5}=$ bankfull discharge $\left(\mathrm{m}^{3} / \mathrm{s}\right)$,

$S=$ bankfull channel slope $(\mathrm{m} / \mathrm{km})$,

$w=$ bankfull channel width $(\mathrm{m})$.

Bankfull discharge $\left(Q_{1.5}\right)$ is defined as being the maximum discharge that the channel can convey without overflowing onto the floodplain, and is defined to be the channel forming discharge in alluvial rivers, with a general recurrence interval of 1.5 years (Leopold et al. 1964; Knighton, 1998). Its estimates at the four gauging stations along Someşul Mic River (Gilău, Cluj-Napoca, Apahida, and Salatiu) were represented in relation with their corresponding drainage surfaces. The resulting relation was further used to extrapolate the bankfull discharge values for each of the 42 considered reaches, by projecting the known values of their equivalent drainage surfaces (GIS estimates) on the resulting curve.

Bankfull channel slope and width were estimated for the unique/main channel. Slope (S) was obtained from the difference in elevation between the two extremes of the considered channel reach (indicated on map at the channel bank level or interpolated from two successive values, at the same level) and the corresponding channel length, measured along central axis of the channel. Bankfull 
Historical geomorphic analysis of Someșul Mic River (NW Romania) channel spatial and temporal behavior, as a background for the assessment of present day morphological state of the river

channel widths (w) were measured in successive cross sections on the central axis of the floodplain. In equation (1), w was introduced as the median values of channel width at channel reach scale. More details on the methodologies of measure- ments, together with a full description on historical channel dynamics of Someșul Mic River are given in Perșoiu, 2010, Perșoiu and Rădoane, 2011, and Rădoane et al., 2013b.

Table 1 Summary of the cartographic supports used in this study

\begin{tabular}{|c|c|c|c|c|c|c|}
\hline Map & Projection & $\begin{array}{c}\text { Topographic } \\
\text { survey }\end{array}$ & Edition & Scale & $\begin{array}{c}\text { Map } \\
\text { resolution }\end{array}$ & $\begin{array}{l}\text { Reference } \\
\text { year con- } \\
\text { sidered in } \\
\text { this study }\end{array}$ \\
\hline $\begin{array}{c}\text { The First Austro-Hungarian } \\
\text { Military Survey (Institute of } \\
\text { Military Geography, Vienna, } \\
\text { Austria) }\end{array}$ & - & $\begin{array}{c}1763-1773 \\
1785 / 1787^{*}\end{array}$ & $1787^{\star}$ & $1: 28.800$ & $\begin{array}{l}\text { Not geo- } \\
\text { referenced }\end{array}$ & 1764 \\
\hline $\begin{array}{l}\text { The Second Austro- } \\
\text { Hungarian } \\
\text { Military Survey (Institute of } \\
\text { Military Geography, Vienna, } \\
\text { Austria) }\end{array}$ & $\begin{array}{l}\text { Cassini-Soldner } \\
\text { projection, } \\
\text { Zach-Oriani } \\
\text { Ellipsoid }\end{array}$ & 1859-1860 & $\begin{array}{c}1869- \\
1870\end{array}$ & $1: 28800$ & $4 \mathrm{~m} /$ pixel & 1860 \\
\hline $\begin{array}{c}\text { The Third Austro-Hungarian } \\
\text { Military Survey (Institute of } \\
\text { Military Geography, Vienna, } \\
\text { Austria) }\end{array}$ & $\begin{array}{l}\text { Tg. Mureş stereo } \\
\text { projection, } \\
\text { Besel } 1841 \text { Ellipsoid }\end{array}$ & 1869-1884 & $\begin{array}{c}1890- \\
1910\end{array}$ & $1: 25000$ & $2 \mathrm{~m} /$ pixel & 1884 \\
\hline $\begin{array}{c}\text { Topographic maps (Romanian } \\
\text { Military Topographic Service, } \\
\text { Bucharest) }\end{array}$ & $\begin{array}{l}\text { Gauss-Kruger } \\
\text { projection, } \\
\text { Pulkovo } 1942 \\
\text { Ellipsoid }\end{array}$ & $\begin{array}{l}\text { Field survey: } \\
\text { 1908-1914 } \\
\text { Aerophotos: } \\
\quad 1956\end{array}$ & 1957 & $1: 25000$ & $2 \mathrm{~m} /$ pixel & 1956 \\
\hline $\begin{array}{l}\text { Topographic plans (Institute } \\
\text { of Geodesy, Photogrammetry, } \\
\text { Cartography and Territorial } \\
\text { Planning, Bucharest, Romania) }\end{array}$ & $\begin{array}{c}\text { Stereo } 70 \\
\text { projection, } \\
\text { Krasovschi Ellipsoid }\end{array}$ & $\begin{array}{l}\text { Aerophotos: } \\
\text { 1968-1976 } \\
\text { Field survey: } \\
\text { 1970-1977 }\end{array}$ & $\begin{array}{c}1971- \\
1979\end{array}$ & $1: 5000$ & $\begin{array}{c}0.4 \\
\mathrm{~m} / \text { pixel }\end{array}$ & 1970 \\
\hline $\begin{array}{l}\text { Topographic maps (Military } \\
\text { Topographic Department, } \\
\text { MApN, Romania) }\end{array}$ & $\begin{array}{l}\text { Gauss-Kruger } \\
\text { projection, } \\
\text { Pulkovo } 1942 \\
\text { Ellipsoid }\end{array}$ & 1977 & $\begin{array}{c}1978- \\
1979\end{array}$ & $1: 25000$ & $2 \mathrm{~m} /$ pixel & 1977 \\
\hline $\begin{array}{l}\text { Orthophotos (National } \\
\text { Agency } \\
\text { for Cadaster and Land } \\
\text { Registration, Bucharest, } \\
\text { Romania) }\end{array}$ & $\begin{array}{c}\text { Stereo } 70 \\
\text { projection, } \\
\text { Krasovschi Ellipsoid }\end{array}$ & 2005 & - & $1: 5000$ & $\begin{array}{c}0.5 \\
\mathrm{~m} / \text { pixel }\end{array}$ & 2005 \\
\hline Google Earth & WGS 1984 & - & - & - & $\begin{array}{l}\text { Google } \\
\text { Earth Data } \\
\text { Repository }\end{array}$ & $\begin{array}{c}2017- \\
2019\end{array}$ \\
\hline
\end{tabular}

4.2 Temporal trends in channel planform behavior

During the last ca. 150 years, the considered channel planform morphometry reveals a general tendency of channel narrowing, channel planform sim- plification and an increased planform stability with some opposite tendencies at decadal scales: increase of sinuosity between AD 1860 - AD1890, followed by decrease during AD 1890 - AD 1956, and a slight recovery during AD 1977 - AD 2005 (Fig. 3). 


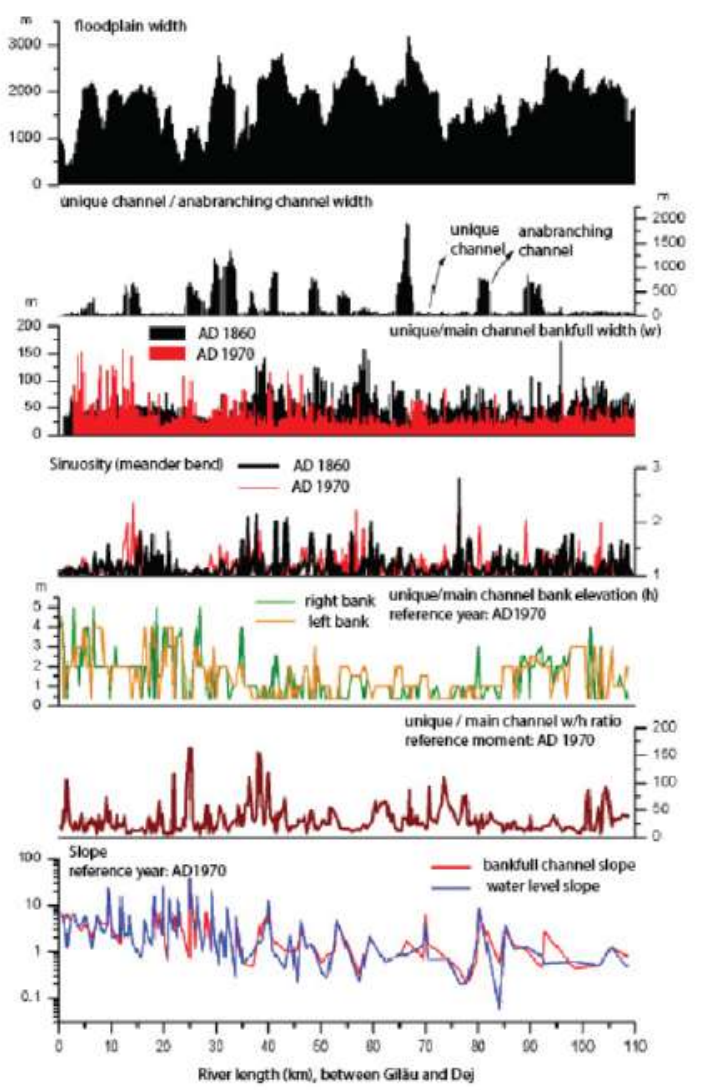

Figure 2 Longitudinal profile variability in the morphometry of Someșul Mic River and its floodplain (reference years: AD 1860 and AD 1970), revealed by systematic measurements in 250 m successive floodplain cross sections and at meander bend scale. It attests a complex spatial succession of unique and anabranching channels, with frequent slope changes, overlapped on frequent narrowing and widening of the floodplain. The main cause for this spatial behavior is attributed to the local geologi-

$$
\text { cal (structural, tectonic) conditions }
$$

The impact of direct human interventions before 1970 's is maintained at local scale, without evident correspondences in the general patterns of the considered morphometric parameters. There are no yet good understanding on the impact of the land use politics from the last decades of the XIX ${ }^{\text {th }}$ century and the first decades of the $X X^{\text {th }}$ century on sediment discharges along the main collector. However, the existing synthesis on sediment budgets and rate of soil erosion on Romanian territory, suggest that the maximum impacts were recorded in the hilly domains and the resulting sediment supplies were preferentially preserved along the small tributaries draining these areas (Dumitriu et al., 2017).

Starting with AD 1977, the human induced changes in the channel morphologies became dominant between Gilău and Apahida: two lakes (Gilău, Florești) and the artificial channel between them replaced the previous channel reaches, anabranching reaches disappeared, and the river was straightened trough meander cutoffs and bank protection measures. Further downstream (e.g. Jucu, Iclod, Ghela, Mănăstirea, Figs. 1, 3), these interventions were smaller, the natural aspect of the channel being preserved.

On this background, the slight tendency to meandering recorded during AD 1977 - AD 2005 reflects local meander developments along non-adjusted channel reaches susceptible to meandering, a process sustained also by the complete elimination of floods after AD 1983. The bankfull channel width followed a similar decreasing trend, generalized along the entire length of the river. This tendency is confirmed by the successive measurements on channel cross sections at the four gauging stations distributed along the river (Șerban, 2007). However, these data support a limited impact of dams on channel incision, with attenuation in the first $30 \mathrm{~km}$ downstream from Gilău Reservoir (Șerban, 2007).

The channel planform dynamics of the past 100 years detailed above was limited compared to those occurring during the previous 100 years (AD 1764 vs. $A D 1860$ reference years, qualitative estimates) (Fig. 4). These differences suggest a dominating centennial scale climate control on channel platform behavior, According to Perșoiu and Rădoane (2011) and Perșoiu and Perșoiu (2019), the cold and humid decades of the late $\mathrm{XVIII}{ }^{\text {th }}$ century (the end of the Little Ice Age), characterized by an increased frequency and magnitude of flood events during $A D$ 1764 - AD 1860, are probably responsible for local avulsions/channel repositioning and cutoffs of previous well-developed meanders, while the ensuing warmer and drier period, with less frequent flood events, favored the development of new generations of meanders along the AD 1860 configured channels. 
Historical geomorphic analysis of Someșul Mic River (NW Romania) channel spatial and temporal behavior, as a background for the assessment of present day morphological state of the river

A
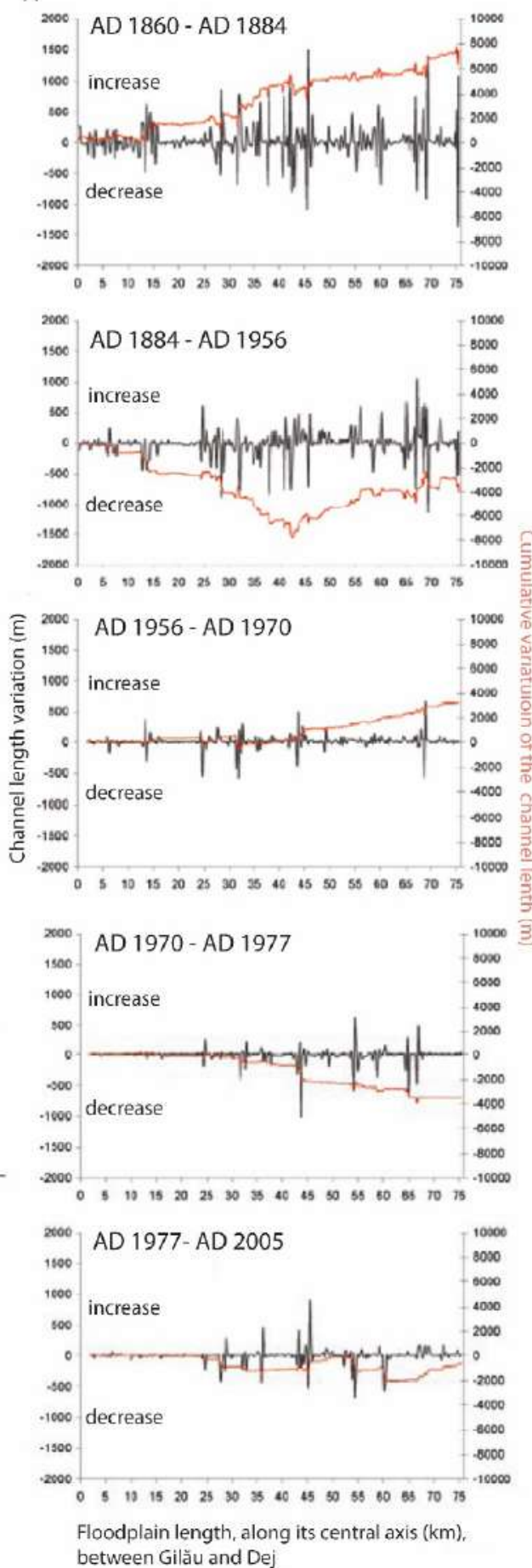

B
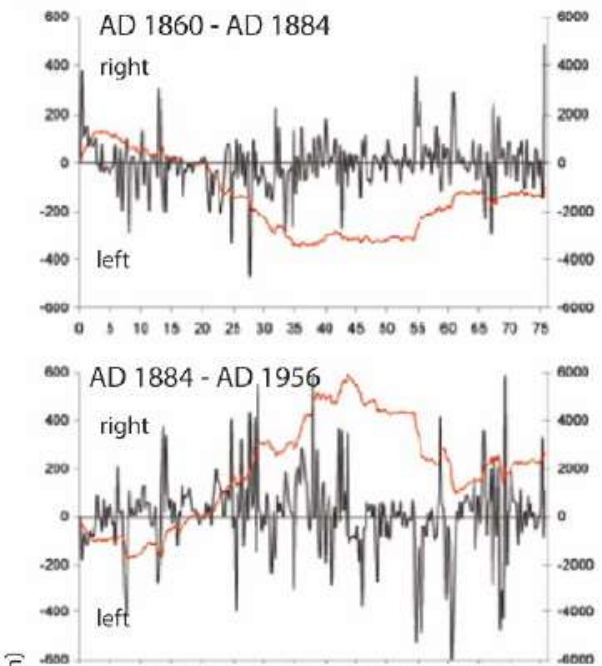



D.

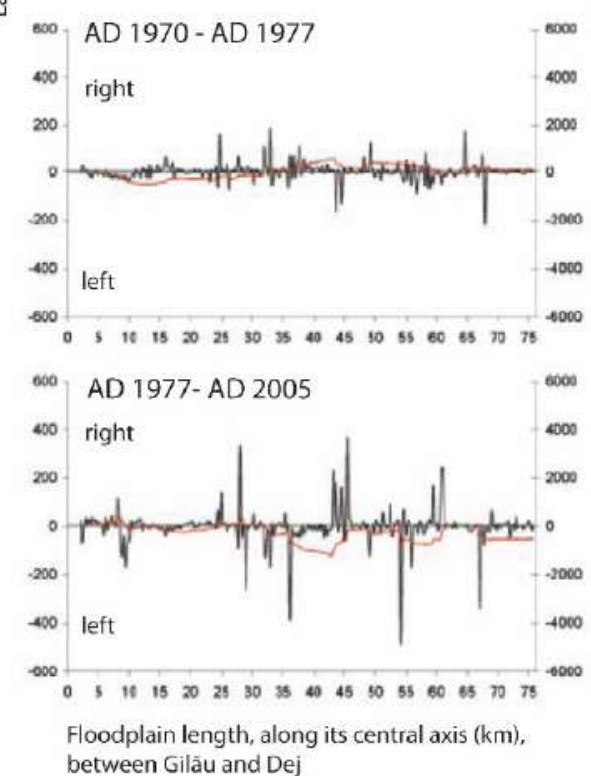

Figure 3 A - Channel length variation and B - Lateral channel movement in successive, $250 \mathrm{~m}$ spaced, cross sections on the floodplain central axis, and their cumulative variations in the longitudinal profile. The two parameters were measured along the central axis of the unique/main channel. Between AD 1860 and AD 1884, the channel length increased, associated with development of meanders along the downstream half of the river. The following phase mark an opposite tendency, up to AD 1970, and reflect mainly the channel shortening along the meandering reaches, both as consequences of natural and artificial cutoffs. The increased channel planform stability after AD 1970 is mainly caused by human interventions along the channel. Local meanders, developed during AD 1977 - AD 2005, are visible in the small scale variations of the two morphometric parameters, subordinated to the general tendencies 
Based on these observations, in the absence of evidences regarding important human induced changes on sedimentary budgets and load regimes during the last ca. 150 years, the main control on general temporal channel planform trends is climate, through its centennial - decadal scale variations in magnitudes and amplitudes of flood events. Most relevant at local scale, conditioning the channel typologies and associated mechanisms of planform and vertical channel adjustments to changes, the local geological conditions and hydro technical works have subordinate effects, translated in preferential locations of meandering and cutoffs, avulsion nodes and associated multichannel flows, or long term stability along natural or artificially induces sinuous channels.

\subsection{Reference condition, boundary condition, and channel sensitivity $v s$. channel resilience to disturbances}

The local geological conditions were found responsible for the complexity of channel typologies, being identified 42 relatively short (hundreds of meter kilometers long) channel reaches of different typologies, translated in long profile variety of alluvial and mixed channel types, with sinuous, meandering or anabranching planform patterns. At historical scale, this geological conditioning is further reflected in preferential locations of meandering and cutoffs, avulsion nodes and associated multichannel flows, or long term stability along sinuous channel reaches (Figs. 2, 5, 6).

The obtained SSP estimates for natural flow regime are considered here as a rough guide of river energy and its long profile variations. They most probably reflect minimum values for mixed/"in rock" channel reaches, or the anabranching ones. Further improvements should be obtained based on the data provided by detailed hydrological measurements and morphological field surveys before the human induced flow regime.

With these known shortcomings, the long profile distribution of SSP is interpreted to reflect the local geologic conditioning on flow organization, with lower values associated to the alluvial reaches along local scale subsidence basins (here the floodplain vertical aggradation is the dominant process), and increased values along reaches were the valley bottom rocks are exposed in the river bed and its banks, as the river sectioned the entire sedimentary sequence of the floodplain, or intersect uplifting tectonic structures.

The quantitative relations between a series of hydro-morphometric parameters (bankfull slope, specific stream power, sinuosity, anabranching index), highlight several aspects of the spatial organization of flow along this particular river: (a) decreases of slope and specific stream power in the downstream direction and from 'bedrock' to mixed and alluvial reaches; (b) normal relation between slope and single-thread channel planform behavior, even if the alluvial and mixed types evolves at different energetic levels; (c) a good "memory" of the initial planform configurations, even if the historical planform configuration could indicate different channel types (e.g. a previous meandering channel, imposed on a diapiric anticline, appears now as a sinuous reach, a state reflecting the advanced phase of reach evolution in the local geological context); (d) superposition of anabranching reaches on the sinuous-meandering ranges, as responses of the river to local conditions; (e) for the mixed type reaches, the rock-alluvium proportion in the channel cross-section seems to be the main control for the channel type (a higher proportion of rock will impose sinuous or sinuous anabranching reaches and an increase of alluvium will favor lateral meandering along the single-thread channel reaches as well as the anabranching ones) (Perșoiu and Rădoane, 2011).

The post 1970's human induced artificial flow regimes and changes in local slopes, as the anabranching and part of meandering reaches were replaced by sinuous ones, together with the continuing tendency of channel narrowing and incision, are expected to be reflected in different values of specific steam power, especially along the first 30 $\mathrm{km}$ of the river, with possible translations in the above mentioned boundary conditions. Therefore, the reference period for assessing the present-day morphological state of the river is considered to be the interval AD 1860 - AD 1970, with AD 1970 as reference period for estimating the boundary conditions in "natural" context, as it reflects the last 
morphological channel configurations before the large scale hydrotechnical works along the rivers and in the catchment areas for which are available detailed morphometric (topographic maps, scale 1:5000) and flow regime estimates (decadal scale measurements at gauging stations). As many local interventions were already reported along the river starting with the XVIII ${ }^{\text {th }}$ century, it is evident that the considered reference interval in assessing the present-day state of the river is not a real natural one. A more proper definition of the proposed reference condition is a river state in which the human impacts are maintained bellow the river sensitivity to disturbances.

\section{Present day morphological state of the river}

The Morphological Quality Index (MQI) is a tool designed to assess, classify and monitor the current morphological state of the rivers (Rinaldi et al., 2013a, Rinaldi et al., 2017). The procedure is a quali- tative one, consisting in 28 indicators selected to assess the longitudinal and lateral channel continuity, its planform pattern, cross section configuration, bed structure and substrate, and vegetation in the riparian corridor. They are grouped in three distinct categories: geomorphological functionality, artificiality and channel adjustments. The resulting scoring, based on expert judgment, leads in the end to the definition of the MQI. The obtained values of this index are in the range of 1 to 0 . According to Rinaldi (2013), MQI = 1 should reflect river morphological state defined by "i) full functionality of geomorphic processes along the reach; ii) the absence or negligible presence of artificial elements along the reach and to some extent (in terms of flow and sediment fluxes) in the catchment; iii) and the absence of significant channel adjustments (configuration, width, bed elevation) over a temporal frame of about 100 years", while MQI $=0$ corresponds to minimum quality.

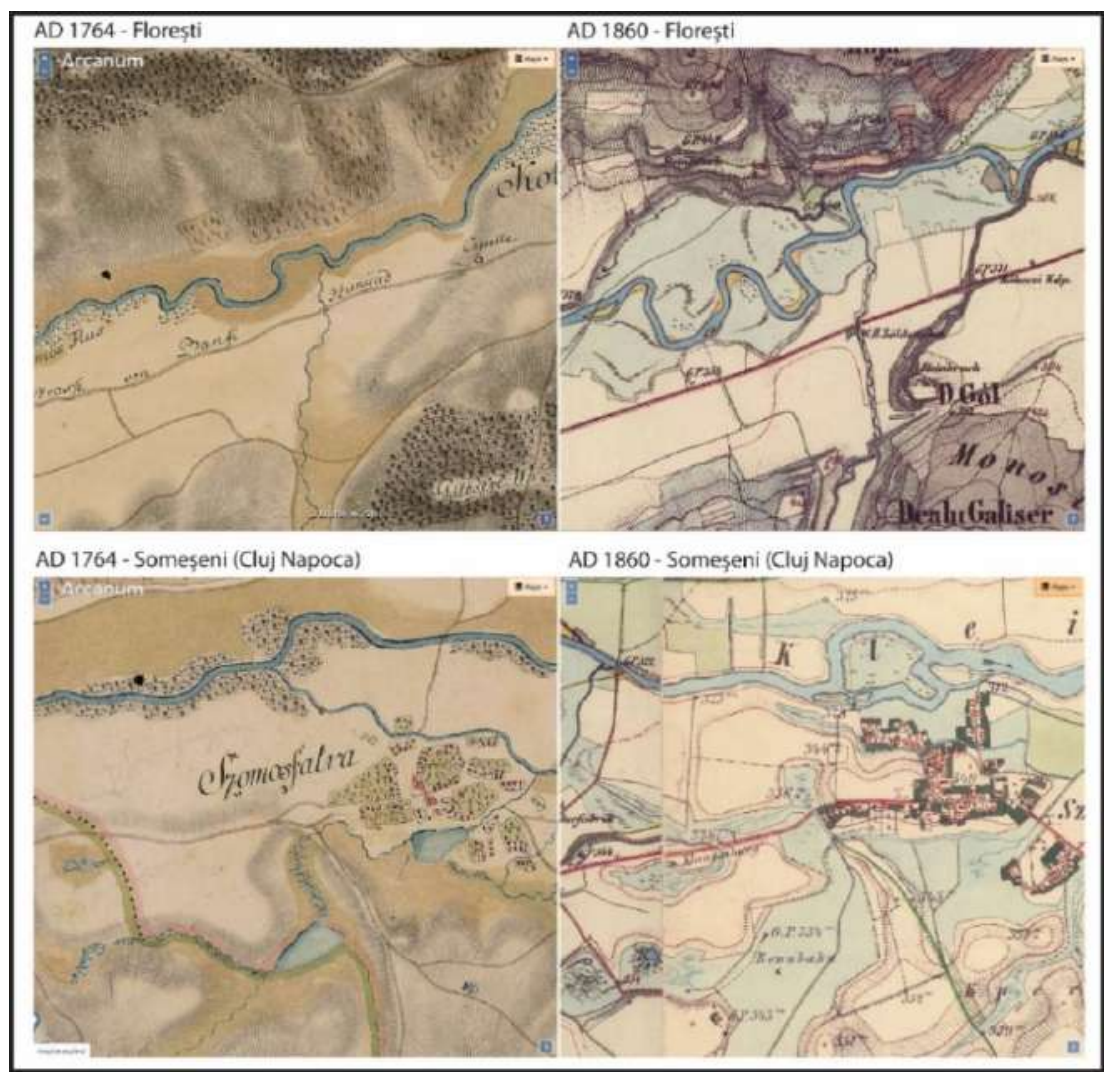

Figure 4 Examples of channel planform changes between AD 1764 and AD 1884: Florești: from a previous sinuous configuration, the channel became meandering; Someșeni (Cluj-Napoca): planform reconfiguration of the anabranching channel reach 
In the case of Someșul Mic River, the process of channel segmentation for assessing its present-day morphologic state (reference period: AD 2015 2019) has considered the distribution of human induces structures along the longitudinal profile (lake, artificial channel, bank protections, meander cutoffs, levees), or, by contrast, their absence and dominance of a more "natural" pattern. We distinguished 17 distinct channel reaches (Table 2 and Fig. 1, Fig. 5). The reference conditions reflect here the channel planform typology as defined at historical scale (AD 1860 - AD 1970) and the boundary conditions indi- cated by specific stream power estimates at $A D$ 1970.

The MQI values (Fig. 7) indicate the high geomorphic degradation of the river induced by the last decadal hydrotechnical interventions along the channel. This finding is in agreement with the poor condition attributed to the river in the National Plan of Water Management 2016 - 2021. The new emerging image attests a further more complex situation in the longitudinal profile. Very poor conditions are concentrated mainly along the first ca. 30 $\mathrm{km}$, while further downstream the river is in a dominating moderate deterioration state.

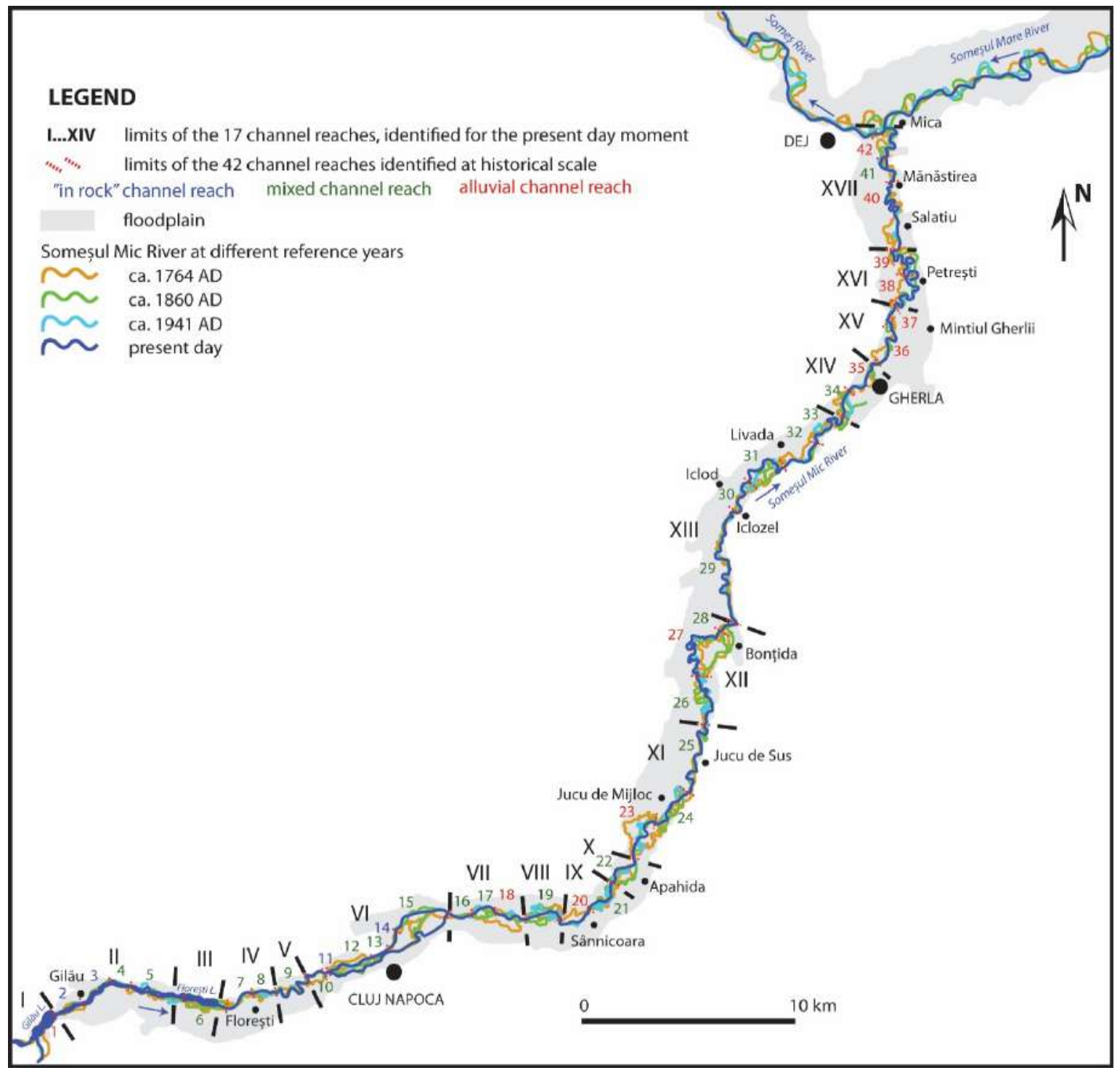

Figure 5 Long profile distribution of the 42 distinct channel reaches identified at historical scale (reference period: $A D 1860$ - AD 1970), and the corresponding 17 channel reaches reflecting the present-day river state, in terms of the degree of human impact on hydro-morphological conditions of the river 
Historical geomorphic analysis of Someșul Mic River (NW Romania) channel spatial and temporal behavior, as a background for the assessment of present day morphological state of the river

Table 2 Channel typologies before large scale human interventions vs. present-day channel types and their Morphological Quality Index (MQI)

\begin{tabular}{|c|c|c|c|c|c|c|}
\hline \multirow[t]{2}{*}{ Reference locality } & \multicolumn{3}{|c|}{$\begin{array}{l}\text { Channel reaches at historical scale } \\
\text { (AD } 1860 \text { - AD 1970) }\end{array}$} & \multicolumn{3}{|c|}{$\begin{array}{l}\text { Present day channel reaches } \\
\text { (AD 1977... AD 2019) }\end{array}$} \\
\hline & Code & $\begin{array}{l}\text { Channel } \\
\text { typology }\end{array}$ & $\begin{array}{c}\text { sSP } \\
\left(\mathrm{W} / \mathrm{m}^{2}\right)\end{array}$ & Code & $\begin{array}{l}\text { Channel } \\
\text { typology }\end{array}$ & $\begin{array}{c}\text { MQI } \\
\text { assessment }\end{array}$ \\
\hline & $\mathrm{R} 1$ & S, alluvial & $?$ & R I & Gilău Lake & 0 \\
\hline \multirow[t]{5}{*}{ Gilău } & $\mathrm{R} 2$ & $\mathrm{~S}$, mixed & 31.12 & R II & $\mathrm{S}$, mixed & 0.2 \\
\hline & R3 & As, mixed & 57.34 & & & \\
\hline & R4 & $\mathrm{S}$, mixed & 29.04 & & & \\
\hline & R5 & M, mixed & 31.61 & & & \\
\hline & R6 & As, mixed & 30.04 & R III & Florești Lake & 0 \\
\hline \multirow[t]{3}{*}{ Florești } & $\mathrm{R} 7$ & $\mathrm{~S}$, mixed & 40.27 & R IV & $\mathrm{S}$, mixed & 0.37 \\
\hline & R8 & $M$, mixed & 46.66 & & & \\
\hline & R9 & M, alluvial & 43.02 & $\mathrm{R} V$ & M, alluvial & 0.45 \\
\hline \multirow[t]{6}{*}{ Cluj-Napoca } & $\mathrm{R} 10$ & S. mixed & 50.51 & R VI & $\mathrm{S}$, mixed & 0.09 \\
\hline & $\mathrm{R} 11$ & $\mathrm{~S}$, mixed & 64.18 & & & \\
\hline & R12 & As, mixed & 44.35 & & & \\
\hline & R13 & S, mixed & 35.58 & & & \\
\hline & R14 & S, mixed & 102.89 & & & \\
\hline & R15 & $\mathrm{S}$, mixed & 31.09 & & & \\
\hline Someșeni (Cluj- & R16 & $\mathrm{S}$, mixed & 68.79 & R VII & $\mathrm{S}$, mixed & 0.25 \\
\hline \multirow[t]{2}{*}{ Napoca) } & $\mathrm{R} 17$ & Am, mixed & 45.32 & & & \\
\hline & $\mathrm{R} 18$ & M, alluvial & 31.01 & & & \\
\hline \multirow{2}{*}{$\begin{array}{l}\text { The International } \\
\text { Aeroport }\end{array}$} & R19 & Am, mixed & 20.03 & R VIII & $\mathrm{S}$, mixed & 0.14 \\
\hline & R20 & S, alluvial & 6.39 & R IX & $\mathrm{S}$, mixed & 0.40 \\
\hline Sânnicoara & R21 & M, mixed & 19.95 & & & \\
\hline \multirow[t]{2}{*}{ Apahida } & R22 & Am, mixed & 76.97 & $\mathrm{RX}$ & S, mixed & 0.29 \\
\hline & R23 & $\begin{array}{l}\mathrm{M}(\mathrm{Am}) \\
\text { alluvial }\end{array}$ & 37.31 & R IX & $\begin{array}{l}\text { S with local } \\
\text { meanders, mixed }\end{array}$ & 0.62 \\
\hline \multirow{3}{*}{ Jucu de Mijloc } & R24 & As, mixed & 43.34 & & & \\
\hline & $\mathrm{R} 25$ & S, mixed & 33.21 & & & \\
\hline & R26 & M, mixed & 46.32 & R XII & Unchanged & 0.30 \\
\hline \multirow[t]{4}{*}{ Bonțida } & $\mathrm{R} 27$ & Am, alluvial & 29.21 & & & \\
\hline & R28 & As, mixed? & 17.73 & & & \\
\hline & R29 & $\mathrm{S}$, mixed & 24.17 & R XIII & S with local & 0.62 \\
\hline & R30 & M, mixed & 50.49 & & meanders, mixed & \\
\hline \multirow[t]{3}{*}{ Iclod } & R31 & Am, mixed & 20.69 & & & \\
\hline & R32 & S, mixed & 17.69 & & & \\
\hline & R33 & M, mixed & 37.20 & & & \\
\hline \multirow[t]{5}{*}{ Gherla } & R34 & Am, mixed & 37.76 & R XIV & $\mathrm{S}$, mixed & 0.17 \\
\hline & R35 & $\begin{array}{l}\mathrm{M}(\mathrm{Am}) \\
\text { alluvial }\end{array}$ & 46.38 & & & \\
\hline & R36 & M, alluvial & 30.01 & $\mathrm{R} X \mathrm{~V}$ & Unchanged & 0.50 \\
\hline & R37 & S, alluvial & 24.82 & & & \\
\hline & R38 & M, alluvial & 11.89 & & & \\
\hline \multirow[t]{2}{*}{ Petrești } & R39 & Am, alluvial & 15.41 & R XVI & S, alluvial & 0.64 \\
\hline & R40 & M, alluvial & 15.58 & R XVII & Unchanged & 0.37 \\
\hline Salatiu & R41 & $\mathrm{S}$, mixed & 50.18 & & & \\
\hline Dej & R42 & M, alluvial & 17.72 & & & \\
\hline
\end{tabular}




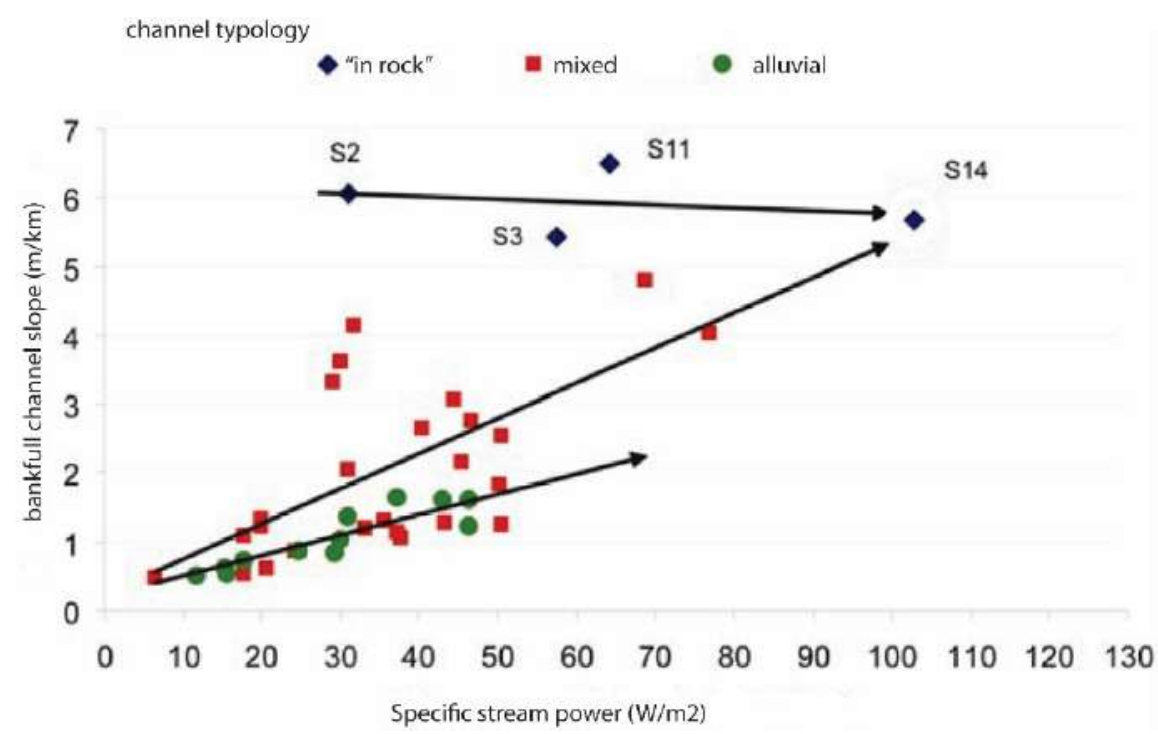

Figure 6 Bankfull slope vs. specific stream power along 42 distinct channel reaches identified at historical scale, before large scale human interventions (reference year: AD 1970, estimates along the unique/main channel)

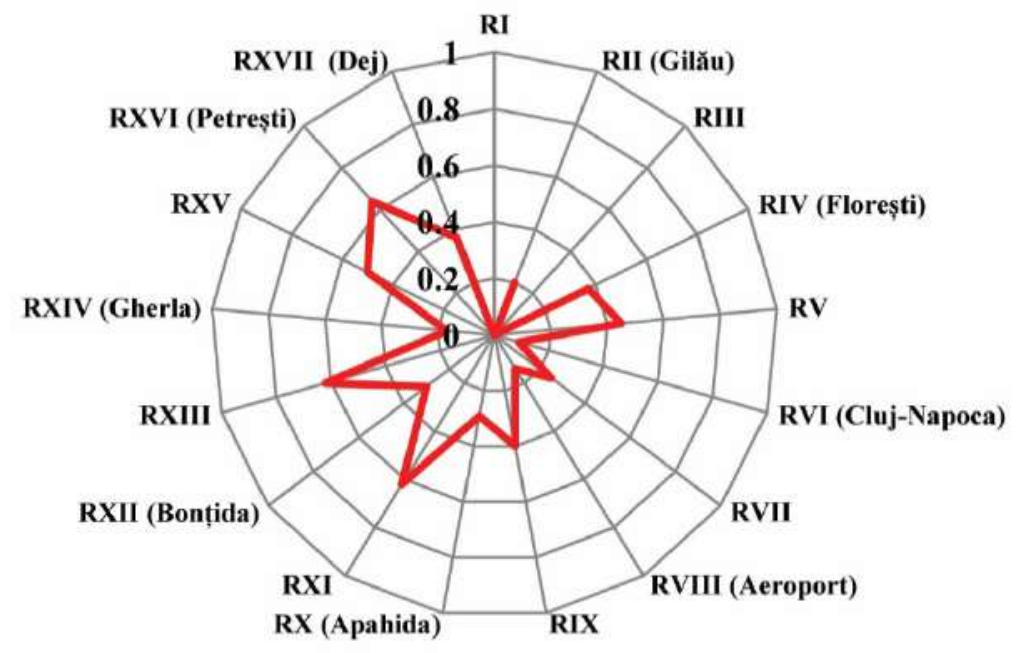

RI-XVII- reaches along the

Figure 7 The Morphological Quality Index (MQI) in 17 distinct channel reaches along Someșul Mic River, reflecting long profile distribution of present-day human induces structures (lake, artificial channel, bank protections, meander cutoffs, levees), or, by contrast, their absence and dominance of a more "natural" pattern. MQI interpretation: 0-0.3: bad; 0.3-0.5: poor; 0.5 - 0.7: moderate; 0.7 / 0.85: good; 0.85 - 1: high

The main causes of disturbances vary from case to case. In the upper reaches of the river, between Gilău and Florești, the artificial diversion of flow and the presence of the two lakes highly influenced the flow regime along Reach II (R II). The decrease of water and sediment discharges downstream of the dams favored the development of riparian vegetation. A deltaic formation is present at the entrance of the river in Florești Lake. Gravel extractions and bank consolidations are responsible for local scale changes in the channel morphology. Downstream from Florești Lake, after an artificially channelized portion (R II), the river passes a short reach where the historical pattern is conserved (R IV), and where human interventions are reduced to levees along the two banks. The next portion corresponds with 
the most deteriorated part of the river, both in terms of aggressiveness (channel straightening, bank consolidations, crossing structures, levees) and affected channel length, and is superimposed on the most developed urban area along the valley, between Cluj-Napoca and Apahida. Intercalated small scale reaches ( $R$ VII, $R$ IX) show tendencies of returning to a natural state, few decades after the local hydrotechnical works and gravel extractions, reflected in the development of riparian vegetation, development of mid-channel islands, and local meandering. Downstream from Apahida (R IX - XVII) the hydrotechnical interventions are further more dispersed and of lower impact. A series of artificial cutoffs and levees are meant to protect local villages at Jucu, Iclod, Petrești, and Gherla city, with the most extensive ones along R XIV (Fig. 7). They are responsible for the elimination of anabranching reaches recorded in the past at Iclod, Gherla and Petrești, and of some of the well-developed meander bents active before 1970's, but as in general, with the exception of Gherla, they do not impose river segmentation and dramatic changes in the historical river typologies. More visible impacts are related to the gravel extraction sites (some of them already abandoned), located both along the channel and in the near vicinity and associated with local changes in planform/cross-section channel morphologies, and floodplain land use practices, responsible for narrowing and deterioration of the riverine vegetation belt.

\section{Conclusions}

The goal of this paper was to demonstrate the usefulness of systematic historic and present-day geomorphic analysis along channel reaches with distinct typologies, part of a multi-scalar, hierarchical, process based hydro-morphological framework focused on understanding river functioning and evolution in interpreting current conditions, as an alternative to physical survey procedures promoted today in the evaluation and classification of the Romanian rivers.

It brings to attention the better perspective on processes, mechanisms and controls acting on a river obtained through a systematic investigation of channel historical behavior, in particular for periods of time when human interventions were more isolated and of lower intensities that in the present, with relevant insights on aspects as channel evolutionary trajectories, previous boundary conditions, sensitivities and resilience, at different scales of space and time. All these elements will further permit to establish a relevant interval of time for reference conditions, together with its meanings in terms of river naturalness, needed to assess the presentday geomorphic state of the river.

In this context, the historical perspective on channel planform dynamics of Someșul Mic River highlights the main role played by centennial and decadal flood patterns (their magnitudes, frequencies) in the ca. 250 years temporal trends of channel behavior. On this background, the local geological conditions are responsible for a complex long profile succession of channel typologies, which further on sustain local tendencies to stability, meandering or avulsion.

In terms of recent human impact, the hydrotechnical interventions along the river are concentrated along the first ca. $30 \mathrm{~km}$ of it, leading to channel straightening, narrowing and incision and more localized further downstream. By comparison, gravel extractions activities are more frequent along the lower half of it (the downstream part of it), and impose significant local changes in the spatial and cross section morphology of the channel, even long time after their abandonments. Agricultural practices in the floodplain perimeter are the third important disturbing elements, responsible for deterioration of the riparian vegetation belt, in terms of size and structure, and is frequently associated with local active bank erosion processes. The cumulative effects of these local scale human disturbances impose the present morphological state of the river, when compared with a reference condition defined as reflecting channel hydro-morphological characteristics between AD 1860 and AD 1970: dominant bad to poor conditions between Gilău and Apahida, and some moderate ones between Apahida and Dej.

The resulted image, characterized by an increased resolution when compared with the existing ones, has the potential to better identify the critical reaches along this river, and the main disturbing 
elements acting on them in order to support and increase in the quality of projections on possible channel trajectories, and of the proposed river management actions.

\section{Acknowledgments}

This work was supported by Romanian Ministry of Education through grants awarded to IP (PNII-RUPD-2012-3-0547; PN-III-P1-1.1-MC-2019-0579). We are grateful to Maria Rădoane, Magda Drăgan, Mirela Câmpean, Karina Battes and the reviewers for their valuable comments.

\section{References}

Amăriucăi M. 2000. Șesul Moldovei extracarpatice dintre Păltinoasa și Roman. Studiu geomorfologic și hidrologic. Carson Press, Iaşi (in Romanian).

Armencea G, Marinescu G, Stoicescu H, Lup I. 1980. Aspects of the channel incision prognosis downstream of dams. Hidrotehnica, 25(2): 11-15 (in Romanian).

Aniţan I. 1974. Maximum discharge in the Someş drainage basin, unpublished PhD Thesis. "Babeş-Bolyai" University, Cluj-Napoca (in Romanian).

Armaș I, Gogoașe-Nistoran DE, Osaci-Costache G, Brașoveanu L. 2012. Morphodynamic evolution patterns of Subcarpathian Prahova River (Romania). Catena, 100: 83-99.

Belletti B, Rinaldi M, Gurnell AM, Buijse AD, Mosselman E. 2015. A review of assessment methods for river hydromorphology. Environ. Earth Sci., 73: 2079-2100.

Brierley GJ, Fryirs KA. 2005. Geomorphology and River Management: Applications of the River Style Framework. Blackwell, Oxford, UK, p. 398.

Brierley GJ, Fryirs KA, Boulton A, Cullum C. 2008. Working with change: the importance of evolutionary perspectives in framing the trajectory of river adjustment. In: Brierley G, Fryirs KA. (eds.): River Futures: an Integrative Scientific Approach to River Repair. Society for Ecological Restoration, International Island Press, Washington, DC, USA, pp. 65-84.

Brierley GJ, Fryirs K, Cullum C, Tadaki M, Huang HQ, Blue B. 2013. Reading the landscape: integrating the theory and practice of geomorphology to develop placebased understandings of river systems. Prog. Phys. Geog., 37: 601-621.

Chiriţă C. -(ed). 1981. Pădurile României. Studiu monographic. Edit. Academiei RSR, Bucureşti. Romania.

Ciomac IL, Popa-Necşa V. 1936. Munţii Apuseni. Cercetări asupra stărilor economice. Tipografia ziarului "Universul", Bucureşti, Romania. 310p.
Ciupagea D et al. 1970. Geologia Depresiunii Transilvaniei. Ed. Acad. RSR, Bucureşti, Romania. 256 p.

Directive 2000/60/EC of the European Parliament and of the Council of 23 October 2000 establishing a framework for community action in the field of water policy. Off. J. L 327, 73, 22/12/2000, Brussels, Belgium.

Dufour S, Piégay H. 2009. From the myth of a lost paradise to targeted river restoration: forget natural references and focus on human benefits. River Res. Appl., 25: 568-581.

Dumitriu D, Rădoane M, Rădoane N. 2017. Sediment Sources and Deliver. In: Rădoane $M$, VespremeanuStroe A. (eds.): Landform Dynamics and Evolution in Romania. Springer, 629-654.

Dumitriu D. 2007. Sistemul aluviunilor din bazinul râului Trotuș. Universităţii Suceava Press, Suceava.

Feurdean A, Tanțău I. 2017. The evolution of vegetation from the Last Glacial Maximum until the Present. In: Rădoane M, Vespremeanu-Stroe A. (eds.): Landform Dynamics and Evolution in Romania. Springer, 67-86.

Feurdean A, Parr CL, Tanţău I, Fărcaş S, Marinova E, Perşoiu I. 2013a. Biodiversity variability across elevations in the Carpathians: parallel change with landscape openness and land use. Holocene, 23(6): 869-881.

Feurdean A, Liakka J, Vanniere B, Marinova E, Mossbruger V, Hickler T. 2013b. Holocene fire regime drivers in the lowlands of Transylvania (Central-Eastern Europe): a data-model approach. Quat Sci Rev, 81: 48-61.

Feurdean A, Astaloș C. 2005. The impact of human activities in the Gutâiului Mountains, Romania. Studia UBB Geologia, 50(1-2): 63-72.

Ficheux R. 1996. Les monts Apuseni (Bihor) - Vallées et aplanissements. Ed. Academiei, Cluj-Napoca, Romania. $535 \mathrm{p}$.

Giurgiu V. 2010. Consideraţii asupra stării pădurilor României. Revista pădurilor, anul 125, nr.2/2010, Bucureşti.

Griffiths P, Kuemmerle T, Baumann M, Radeloff WC, Abrudan IV, Lieskovsky J, Munteanu C, Ostapowicz K, Hostert P. 2014. Forest disturbances, forest recovery, and changes in forest types across the Carpathian ecoregion from 1985 to 2010 based on Landsat image composites. Remote Sensing of Environment, 151: 72-88.

Gurnell AM, Rinaldi M, Buijse AD, Brierley $G$, Piegay $H$. 2016a. Hydromorphological frameworks: emerging trajectories. Aquat. Sci., 78: 135-138.

Gurnell AM, Belletti B, Bizzi S, Blamauer B, Braca G, Buijse $A D$, Bussettini $M$, Camenen B, Comiti F, Demarchi $L$, Garcia De Jalon D, Gonzalez Del Tanago M, Grabowski RC, Gunn IDM, Habersack H, Hendriks D, Henshaw A, Kleosch M, Lastoria B, Latapie A, Marcinkowski P, Martinez-Fernandez V, Mosselman E, Mountford JO, Nardi L, Okruszko T, O'Hare MT, Palma M, Percopo C, Rinaldi 
Historical geomorphic analysis of Someșul Mic River (NW Romania) channel spatial and temporal behavior, as a background for the assessment of present day morphological state of the river

M, Surian N, van de Bund W, Weissteiner C, Ziliani L. 2016b. A multi-scale hierarchical framework for developing understanding of river behaviour. Aquat. Sci., 78: $1-16$.

Hoffmann T, Lang A, Dikau R. 2008. Holocene river activity: analysing $14 \mathrm{C}$-dated fluvial and colluvial sediments from Germany, Quaternary Science Reviews, 27: 2031-2040.

Knighton D. 1998. Fluvial Forms \& Processes - a new perspective. Oxford University Press Inc., 400 p.

Krezsek C, Bally AW. 2006. The Transylvanian Basin (Romania) and its relation to the Carpathian fold and thrust belt: Insights in gravitational salt tectonics. Marine and Petroleum Geology, 23: 405-442.

Kondolf M, Piegay $\mathrm{H}$. (eds.) 2016. Tools in fluvial geomorphology. John Wiley \& Sons, Ltd. 560 p.

Liébault F, Piégay H. 2001. Assessment of channel changes due to long-term bedload supply decrease, Roubion River, France. Geomorphology, 36: 167-186.

Liébault F, Piégay H. 2002. Causes of 20th century channel narrowing in mountain and piedmont rivers of southeastern France. Earth Surf Proc Land, 27: 425-444.

Leopold LB, Wolman MG, Miller JP. 1964. Fluvial Processes in Geomorphology. San Francisco: WH Freeman. 522p.

Munteanu C, Kuemmerle T, Boltiziar M, Butsic V, Gimmi U, Haladad L, Kaimh D, Királyi G, Konkoly-Gyurój E, Kozakh J, Lieskovsky J, Mojses M, Müller D, Ostafin K, Ostapowicz K, Shandra O, Stych P, Walker S, Radeloff WC. 2014. Forest and agricultural land change in the Carpathian region - A meta-analysis of long-term patterns and drivers of change. Land Use Policy, 38: 685-697.

Pandi G. 1997. Concepţia energetică a formării şi transportului aluviunilor în suspensie - Aplicaţie în NV Romaniei. Presa Universitară Clujeană.

Perșoiu I, Perșoiu A. 2018. Flood events in Transylvania during the Medieval Warm Period and the Little Ice Age. The Holocene, 29(1): 85-96. https://doi.org/10.1177/0959683618804632.

Perșoiu I, Feurdean A, Perşoiu A, Rădoane M, Robu D, Tanţău I. 2016. Late Quaternary floodplain evolution in the Transylvanian tablelands, Romania. Carpatho-Balkan-Dinaric Geomorphological Commission, Conference Proceedings.

Perşoiu I, Rădoane M. 2011. Spatial and temporal controls on historical channel responses - study of an atypical case: Someșul Mic River, Romania. Earth Surf Land Proc, 36(10): 1391-1409.

Perşoiu I. 2010. Reconstruction of Holocene geomorphological evolution of Someșul Mic Valley. Unpublished PhD thesis "A. I. Cuza" University, Iași, Romania (in Romanian).
Pop GP. 1996. România - geografie hidroenergetică. Ed. Presa Universitară Clujeană, Cluj-Napoca.

Posea G. 1962. Aspecte de relief din jurul Clujului. Analele Universităţii din Bucureşti, Seria Geografie, 32: 119-139.

Posea G, Popescu N, Ielenicz M. 1974. Relieful României. Ed. Ştiintifică, Bucureşti. 483 p.

Rădoane M, Perșoiu I, Chiriloaei F, Cristea I, Robu D. 2017. Styles of Channel Adjustments in the Last 150 Years. In: Rădoane M, Vespremeanu-Stroe A. (eds.): Landform Dynamics and Evolution in Romania. Springer, 489-518.

Rădoane M, Obreja F, Cristea I, Mihailă D. 2013a. Changes in the channel-bed level of the eastern Carpathian Rivers: climatic vs. human control over the last 50 years. Geomorphology, 193: 91-111.

Rădoane M, Perșoiu I, Cristea I, Chiriloaei F. 2013b. River channel plan channel planform change based on successive cartographic data. A methodological form change based on successive cartographic data. Revista de Geomorfologie, 15: 69-88.

Rădoane M, Pandi G, Rădoane N. 2010. Contemporary bed elevation changes from the Eastern Carpathians. Carpathian J Earth Environ Sci, 5: 49-60.

Rădoane M, Rădoane N. 2009. Monitoring of the Moldova River channel changes in the Preuteşti - Timişeşti gravel extractions area. In: Irimuş IA (ed.): Geografia în contextul dezvoltării contemporane. Presa Universitară Clujeană: Cluj-Napoca; 160-175 (in Romanian).

Rădoane M, Rădoane N. 2005. Dams, sediment sources and reservoir silting in Romania. Geomorphology, 71: 217-226.

Rinaldi M, Belletti B, Bussettini M, Comiti F, Golfieri B, Lastoria B, Marchese E, Nardi L, Surian N. 2017. New tools for the hydromorphological assessment and monitoring of European streams. Journal of Environmental Management, 202: 363-378.

Rinaldi M, Bussettini M, Surian N, Comiti F, Gurnell AM. 2016. Guidebook for the Evaluation of Stream Morphological Conditions by the Morphological Quality Index (MQI). Version 2. Istituto Superiore per la Protezione e la Ricerca Ambientale.

http://www.isprambiente.gov.it/it/pubblicazioni/manuali-e-lineeguida/guidebook-for-the-evaluation-ofstream.

Rinaldi M, Surian N, Comiti F, Bussettini M. 2013a. A method for the assessment and analysis of the hydromorphological condition of Italian streams: the Morphological Quality Index (MQI). Geomorphology, 180-181: 96-108.

Rinaldi M, Wyzga B, Dufour S, Bertoldi W, Gurnell A. 2013b. River Processes and Implications for Fluvial Ecogeomorphology: A European Perspective. In: Shroder J. (editor in chief), Butler DR, Hupp CR. (eds.): 
Treatise on Geomorphology. Academic Press, San Diego, CA, vol. 12, Ecogeomorphology, 37-52.

Rinaldi M. 2003. Recent channel adjustments in alluvial rivers of Tuscany, Central Italy. Earth Surf Proc Land, 28: $587-608$.

Robu D. 2018. Evolution of the river network in the Lower Somes, Plain. Unpublished PhD thesis, "Ștefan cel Mare" University, Suceava, Romania (in Romanian).

Savu A. 1964. Someşan Plateau - geomorphological study. Unpublished PhD thesis, "Babeș - Bolyai" University, Cluj-Napoca, Romania (in Romanian).

Sümegy P. 1999. Reconstruction of flora, vegetation and landscape evolution, and human impact on the Bereg Plain from late-glacial up to the present, based on palaeoecological analysis. The Upper Tisza valley, 171-203.

Surian N, Rinaldi M. 2003. Morphological response to river engineering and management in alluvial channels in Italy. Geomorphology, 50: 307-326.
Şerban G. 2007. Lacurile de acumulare din bazinul hidrografic superior al Someşului Mic - studiu hidrogeografic. Presa Universitară Clujeană.

Ioana-Toroimac G, Dobre R, Grecu F, Zaharia L. 2010. A 2D active-channel's evolution of the Upper Prahova River (Romania) during the last 150 years. GeomorphotRelief Processus Environ, 3: 275-286.

Zugrăvescu D, Polonic G, Horomcea M, Dragomir V. 1998. Recent vertical crustal movements on the Romanian territory, major tectonic compartments and their relative dynamics. Revue Romaine de Geophysique, 42: 314.

Winterbottom SJ. 2000. Medium and short-term channel planform changes on the rivers Tay and Tummel, Scotland. Geomorphology, 34: 195-208.

*** National Plan of Water Management 2016-2021 Plan de Management actualizat al spațiului hidrografic Someș - Tisa, 2016-2021, Ministerul Mediului, Apelor și Pădurilor \& Administrația Națională "Apele Române" (http://www.rowater.ro) 